\title{
Interdisciplinary approaches for analysing governance challenges across the Rhône basin
}

\author{
Christian Bréthaut $\cdot$ Margot Hill Clarvis
}

Received: 17 November 2014/ Accepted: 10 December 2014/Published online: 25 December 2014

(C) Springer-Verlag Berlin Heidelberg 2014

\begin{abstract}
The Rhône basin is one of Europe's major rivers. It stretches from its source in the Swiss Alps through to the Lake Geneva and then down through France to its mouth on the Mediterranean Sea, where its delta constitutes the Camargue Region. It crosses three different 'cantonal' jurisdictions in Switzerland alone, while its course through Lake Geneva itself demarcates the border between France and Switzerland. This presents a valuable opportunity to analyse the multitude of challenges that face the management of a river flowing through such a variety of different hydrological contexts and institutional settings (Swiss, French and European). For the first time, this special issue collates interdisciplinary insights into the challenges faced by the governance systems across the entire Rhône basin. Papers present insights into barriers and opportunities for effectively responding to the many political, economic and climatological challenges facing the managers of the River Rhône overthe coming decades.
\end{abstract}

Keywords Rhône basin - Climate change impacts · Water governance $\cdot$ River basin management $\cdot$ Adaptability

\section{Interdisciplinary insights into responding to multiple pressures on the Rhône}

Climate change impacts are being increasingly observed in major river basins across the world, not least on the Rhône, one of Europe's major river basins. Shifting hydrological baselines and demographic pressures place ever greater

C. Bréthaut $(\bowtie) \cdot$ M. H. Clarvis

Institute for environmental sciences, University of Geneva, D,

7 Rte de Drize, Carouge 1227, Switzerland

e-mail: christian.brethaut@unige.ch pressures on the water governance and management regimes, across multiple sectors and levels. These pressures will only be further exacerbated by future intensifying climate change impacts, which are likely to affect both the timing and seasonality of hydrological regimes, affecting sectors such as hydroelectricity and agriculture (Beniston and Stoffel 2014). Furthermore augmented water temperatures and associated quality changes are likely to have significant repercussions for aquatic and riparian ecosystems as well as for the man-made infrastructure such as hydropower systems and the cooling systems of nuclear power stations in the French section of the basin (Gaudard et al. 2014; Khamis et al. 2014; Pellicciotti et al. 2014).

These challenges call for an in-depth investigation of the linked social-ecological systems (SES), governance regimes and adaptive capacities across the Rhône basin to climate change impacts and broader environmental change drivers. Major questions relate to whether the governance framework of the Rhône is adequately adaptable to cope with current and future stresses; what are the current tensions in the governance framework at different scales; what are the existing major challenges in relation to a disconnect between ecological and institutional boundaries; whether or not an integrative and adaptive approach is possible in a transboundary context without a framework agreement in place (Adger et al. 2009; Bréthaut and Pflieger 2013; Hill and Engle 2013; Lebel et al. 2010; Pahl-Wostl et al. 2008).

\section{The Rhône basin: multiplicity of contexts}

The River Rhône is characterised by different hydrological patterns. It emerges as run-off from the Rhône Glacier at an altitude of 1,753 m in Canton Valais, Switzerland. From here to its mouth on the Mediterranean Sea in France, it 
transforms from a glacial torrent to highly controlled waterway as it passes through the Rhône Valley. At Villeneuve, the Rhône flows into the Lake Geneva (called Lac Léman in French, see Fig. 1), one of the largest lakes in Western Europe, and itself a border between France and Switzerland. At its exit in Geneva, the river then joins with the Arve (from the Mont Blanc, the Alps' highest mountain at $4,810 \mathrm{~m}$ ) and goes through the border to enter the French territory. The river then flows on $522 \mathrm{~km}$ to reach the Mediterranean Sea. The French Rhône is highly channelled with few portions of the river that have not been strongly modified by human activities. The total area of the river basin is $96,500 \mathrm{~km}^{2}, 8,000 \mathrm{~km}^{2}$ of which is in Switzerland (Fig. 1).

\section{Upper Rhône}

The upper Rhône basin is situated in the Canton Valais and Vaud, where the run-off regime is characterised as nivoglacial, with lower discharge in winter than in summer. Glaciers have a significant role in the hydrological regime of the upper Rhône since they cover about $10 \%$ of the area, and contribute on average $10 \%$ of annual surface

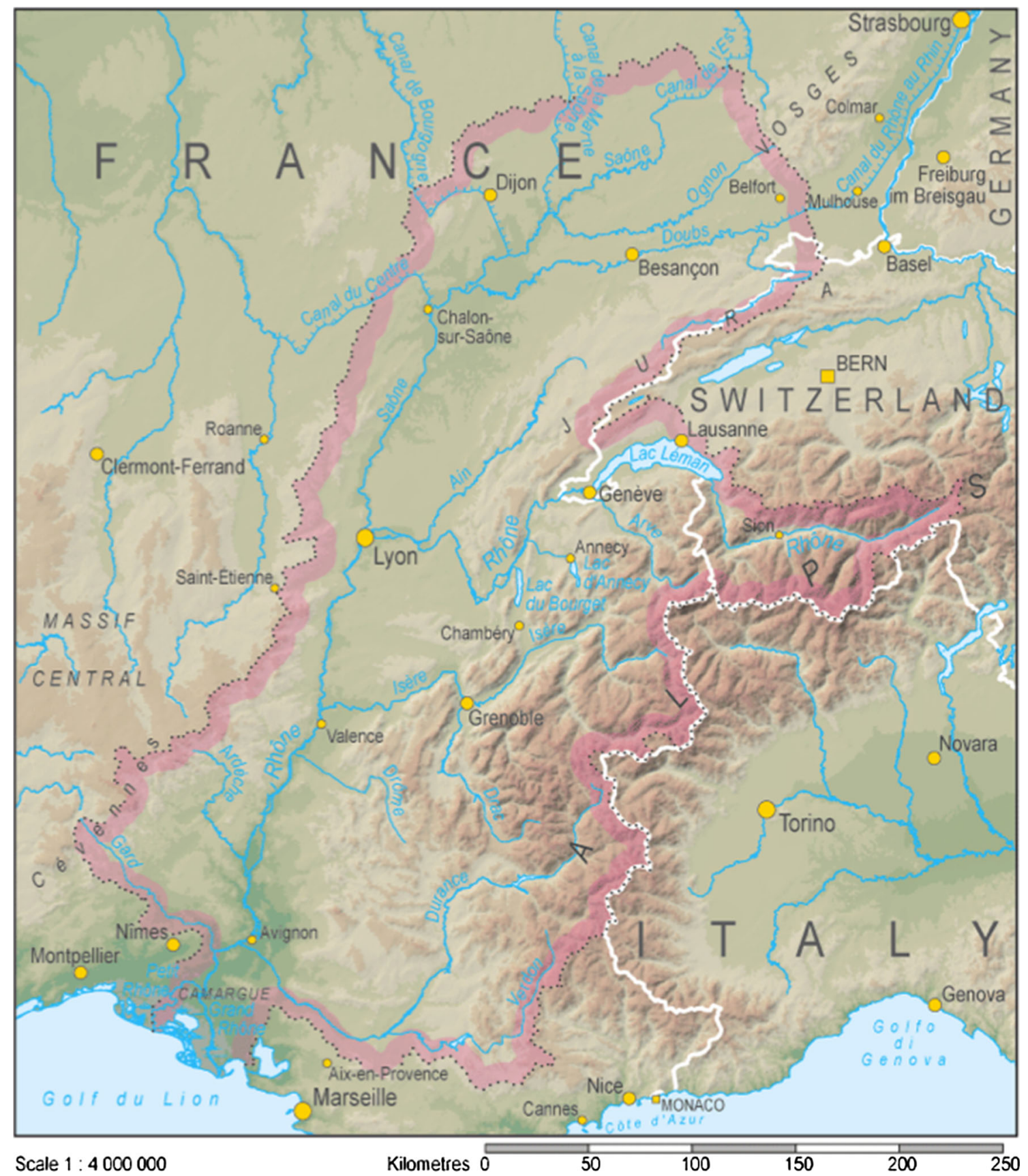

Fig. 1 Rhône basin (Source: UNEP-DEWA-GRID) 
run-off (30-40\% in summer) in the catchment. Precipitation within this part of the basin is highly variable with relatively dry inner valleys with less than $600 \mathrm{~mm}$ of precipitation per year to very wet mountains with more than 2,500 $\mathrm{mm}$ per year (Clarvis et al. 2014). The river and its tributaries supply water resources to a range of diverse economic uses, including hydropower, agriculture, chemical industry and tourism. At one point, the River Rhône becomes the border between the cantons of Valais and Vaud, and the river system is governed by both cantonal and federal legislation, while, in the Canton of Valais, all lateral rivers are under the sovereignty of the communes, which represent major issues regarding management of water (Bréthaut 2013). Following on from a series of major flooding events in recent decades, the Third Rhône Correction is currently underway to enhance both the infrastructural defences and the natural condition of the river for increased flood protection (Hill 2013).

\section{The Lake Geneva area}

After flowing through the Rhône valley in the Canton Valais, the Rhône River enters the Lake Geneva. The lake occupies an area of $582 \mathrm{~km}^{2}$, representing an 89-billioncubic-metre freshwater reservoir that supports the production of drinking water supply. The lake is divided between France and Switzerland with a border that was settled in the Convention on the Delimitation of the Boundary in Lake Geneva of 25 February 1953. Different institutional levels characterise the management of the lake including the legislation of the European Union, the states of France and Switzerland, the cantons of Geneva, Vaud, Valais, the French departments of Ain and Haute-Savoie and one French region, the Rhône-Alpes region.

\section{The Rhône from the Lake Geneva to the Swiss border}

At the outlet of Lake Geneva, the Rhone tightens and passes the city of Geneva. Here, different infrastructures regulate the flows of the river and, by doing so, the levels of the lake. The management of the lake's levels is informed by the convention signed by the Swiss cantons only (despite the fact that part of the shore belongs to France) to avoid flooding and to ensure the navigation on the lake. The management of the river from Geneva to the Swiss border is governed by the Industrial Services of Geneva, a semi-private company producing hydroelectricity.

\section{The French basin}

After the Swiss border, the Rhône River flows south to the Mediterranean Sea. On its course, the river supplies a range of water uses including hydropower production, nuclear energy production (four nuclear power plants), irrigation, fishing, production of drinking water, tourism and ecosystems needs. The river passes through several urbanised areas, such as Lyon. The French part of the Rhône basin experienced several flooding events between 2000 and 2003 that led to the implementation of the Plan Rhône, a policy instrument aiming to manage the river in a coordinated manner and to avoid flood risks within the French part of the basin (Guerrin 2014). From the city of Arles, the river splits into two branches, creating the delta of the Camargue.

\section{The Rhône basin: a context of changes}

The Rhône basin is undergoing several changes that have a significant impact of its governance mechanisms. Climate change is leading to a tendency for more extreme events (droughts and floods), increased glacier reduction, and altering snow melt and fall conditions, which are driving significant modifications to the varying hydrological regimes across the Rhône basin (Beniston et al. 2011; Chauveau et al. 2013). Not only are the climatic and hydrological conditions shifting, but crucial developments in the policy environment are altering the preference of different water uses, notably flood policy, environmental protection policies and energy policies. Energy policies are evolving to favour renewable sources of production and hydropower production in particular. This evolution is reflected in the reinforcement of environmental legislations with the influence of European Union legislations (Water Framework Directive) and the development of French and of the Swiss water law. Finally, the management of the Rhône is also influenced by the liberalisation of European electricity production market. On the French side, the management of the Rhône is delegated to one main private operator under the concession system. Signed for a period of 99 years, this concession will end in 2023. This rapidly approaching date opens up a new era for how actor configurations will evolve around the management of the Rhône.

\section{Analysing drivers to change at micro- and macrolevels across the basin}

For the first time, this special edition brings together a set of papers that focus on the governance and management of one single river basin system, the Rhône, presenting insights from research that stretches from the upper Rhône in Switzerland to the delta in France. Many of these papers take a cross-scale and interdisciplinary approach, across both temporal and spatial scales in order to better 
understand the complexity of both the governance and physical dynamics at play. Studies presented come mainly from the social sciences, but also reflect an interdisciplinary approach to assessing drivers and responses to change at micro- and macrolevels across the basin. Through this issue, our aim is to contribute to a better understanding of the multiple social-ecological dynamics at play at different points of the basin and therefore to build a more comprehensive picture of the resilience of the basin as a whole.

Ruiz-Villanueva et al. (2014) analyse the effects of climate change on the Rhône River mean flows from 1960 till 2100. Authors focus on the perimeter going from Lake Geneva to the city of Lyon, which is highly relevant as it concerns the transboundary perimeter, which regroups coordination issues between Switzerland and France. Authors combine statistical analysis and climate modelling in order to identify different scenarios and their effects on hydrology and on governance mechanisms. This paper sets the broad context of this special issue by showing the intensity of environmental changes that the river experiments.

Clarvis and Engle (2013) raise the issue of adaptation. Facing these significant changes, stakeholders implement different strategies in order to cope with the new contexts. The authors analyse the bridges and barriers to adaptation. Comparing one case situated in the upper Rhône and one case situated in the USA, they show the importance of collaboration and transversality between different institutional levels, when adopting measures for better adaptive capacities.

Ingold and Balsiger (2013) also highlight the importance of cross-sectoral and multilevel collaboration by focusing on climate adaptation policies. Working on case studies situated in the upper Rhône and in western Switzerland, they analyse collaboration among local actors by using surveys that have been analysed through cluster and social network analysis. Authors show that collaboration can happen among actors sharing different views regarding the meaning of sustainability and on the implementation of localised projects.

Tonka (2014) compares hydropower regulatory frameworks of USA and Switzerland and analyses the different issues at play in each country regarding the relicensing processes of dams. This paper shows how the end of concession contracts granted for several decades opens up a new era and significant instabilities among the configurations of actors. Under changing climatic conditions, the relicensing process offers the chance to rethink the waterenergy nexus and the adaptation capacities of the system.

Bréthaut and Pflieger (2013) focus on the transboundary management of the Rhône River. Authors show the difficulties in implementing collaboration when the governance system is comprised of such different types of actors, legal frameworks and institutional levels. Through an historical institutional analysis, they illustrate how the Rhône river governance evolves leading to more complexity and increasing rivalries among users.

Finally, Guerrin (2014) analyses failure of floodplain restoration projects. Using indicators developed through preceding literature and addressing both theory and practice, the author illustrates how institutional factors have played a critical role in the failure. Specifically, the paper focuses on the Plan Rhône, a policy instrument developed at the French Rhône River basin level.

This set of articles presents different answers to the changes experimented by the Rhône River basin. It shows how an increasing complexity calls for institutional answers and illustrates the challenges that stakeholders have to face. Authors present different issues regarding the management of the river and the difficulties to implement a multilevel or cross-sectoral governance system. Moreover, the insights presented from the range of studies across one single river basin illustrate the strong diversity of institutional structures, policy objectives and "cultures" of collaboration.

\section{References}

Adger WN, Dessai S, Goulden M, Hulme M, Lorenzoni I, Nellson DR, Naess LO, Wolf J, Wreford A (2009) Are there social limits to adaptation to climate change? Clim Change. doi:10.1007/ s10584-008-9520-Z

Beniston M, Stoffel M (2014) Assessing the impacts of climatic change on mountain water resources. Sci Total Environ 493:1129-1137. doi:10.1016/j.scitotenv.2013.11.122

Beniston M, Stoffel M, Hill M (2011) Impacts of climatic change on water and natural hazards in the Alps: can current water governance cope with future challenges? Examples from the European "ACQWA" project. Environ Sci Policy 14:734-743. doi:10.1016/j.envsci.2010.12.009

Bréthaut C (2013) Gestion des réseaux urbains de l'eau en stations touristiques alpines. Rüegger, Zürich. ISBN 978-3-7253-1014-2

Bréthaut C, Pflieger G (2013) The shifting territorialities of the Rhone River's transboundary governance: a historical analysis of the evolution of the functions, uses and spatiality of river basin governance. Reg Environ Change. doi:10.1007/s10113-0130541-4

Chauveau M, Chazot S, Perrin C, Bourgin PY, Sauquet E, Vidal JP, De Lacaze X (2013) Quels impacts des changements climatiques sur les eaux de surface en France à l'horizon 2070? La Houille Blanche 4:5-15. doi:10.1051/lhb/2013027

Clarvis MH, Fatichi S, Allan A, Fuhrer J, Stoffel M, Romerio F, Gaudard L, Burlando P, Beniston M, Xoplaki E, Toreti A (2014) Governing and managing water resources under changing hydroclimatic contexts: the case of the upper Rhone basin. Environ Sci Policy 43:56-67. doi:10.1016/j.envsci.2013.11.005

Clarvis MH, Engle N (2013) Adaptive capacity of water governance arrangements: a comparative study of barriers and opportunities in Swiss and US states. Reg Environ Change. doi:10.1007/ s10113-013-0547-y 
Gaudard L, Romerio F, Dalla Valle F, Gorret R, Maran S, Ravazzani G, Stoffel M, Volonterio M (2014) Climate change impacts on hydropower in the Swiss and Italian Alps. Sci Total Environ 493:1211-1221. doi:10.1016/j.scitotenv.2013.10.012

Guerrin J (2014) A floodplain restoration project on the River Rhône (France): analyzing challenges to its implementation. Reg Environ Change. doi:10.1007/s10113-014-0650-8

Hill M (2013) Adaptive capacity of water governance: cases from the Alps and the Andes. Mt Res Dev 33:248-259. doi:10.1659/ MRD-JOURNAL-D-12-00106.1

Hill M, Engle NL (2013) Adaptive capacity: tensions across scales. Environ Policy Gov 23:177-192. doi:10.1002/eet.1610

Ingold K, Balsiger J (2013) Sustainability principles put into practice: case studies of network analysis in Swiss climate change adaptation. Reg Environ Change. doi:10.1007/s10113-0130575-7

Khamis K, Hannah DM, Clarvis MH, Brown LE, Castella E, Milner AM (2014) Alpine aquatic ecosystem conservation policy in a changing climate. Environ Sci Policy 43:39-55. doi:10.1016/j. envsci.2013.10.004

Lebel L, Grothmann T, Siebenhüner B (2010) The role of social learning in adaptiveness: insights from water management. Int
Environ Agreem Polit Law Econ 10:333-353. doi:10.1007/ s10784-010-9142-6

Pahl-Wostl C, Tabara D, Bouwen R, Craps M, Dewulf A, Mostert E, Taillieu $T$ (2008) The importance of social learning and culture for sustainable water management. Ecol Econ 64:484-495. doi:10.1016/j.ecolecon.2007.08.007

Pellicciotti F, Carenzo M, Bordoy R, Stoffel M (2014) Changes in glaciers in the Swiss Alps and impact on basin hydrology: current state of the art and future research. Sci Total Environ 493:1152-1170. doi:10.1016/j.scitotenv.2014.04.022

Ruiz-Villanueva V, Stoffel M, Bussel G, Francés F, Bréthaut C (2014) Climate change impacts on discharges of the Rhone River in Lyon by the end of the twenty-first century: model results and implications. Reg Environ Change. doi:10.1007/s10113-0140707-8

Tonka L (2014) Hydropower license renewal and environmental protection policies: a comparison between Switzerland and the USA. Reg Environ Change. doi:10.1007/s10113-014-0598-8 